\title{
PALYNOLOGY OF THE LATE NEOGENE, INTERCEPTED IN A BOREHOLE FROM CERNEȚI (EAST OF TURNU SEVERIN)
}

\author{
IUSTINIAN PETRESCU ${ }^{1}$, NICOLETA BICAN-BRIŞAN ${ }^{1}$, \\ CORNEL MEILESCU ${ }^{2}$, LIANA TUNSOIU ${ }^{1}$
}

\begin{abstract}
The paper presents the results of the palynologic studies carried on the samples recovered the W1 well from Cerneți. These rocks were assigned to Meotian and Pontian deposits. The Meotian deposits, $40 \mathrm{~m}$ thick are characterized by a palynological spectrum consisting from: Ferns (3-4\%), Conifers (56-62\%), Monocotyledonous Angiosperms (1-2\%), Dicotyledonous Angiosperms (33-40\%). The microflora was compared with the pollinic spectrum from the Late Meotian deposits between Teleajen and Dâmbovița (Cioflică, 1969). The Pontian intercepted between m 112 and m 36 keeps a relatively uniform microflora: Ferns (5\%), Conifers $(60 \%)$, Monocotyledonous Angiosperms (1\%), Dicotyledonous Angiosperms (34\%). This microflora was compared with the pollinic spectrum from the Lower Pontian deposits from Batoti and from the Upper Pontian deposits from V. Vişenilor and V. Boierească. The paper infers on paleoclimatic circumstances specific to the forest vegetation during the Meotian and Pontian times, and also contains a reconstitution of the source vegetation for the studied and identified sporo-pollinic material.
\end{abstract}

Keywords: microflora, Late Neogene, Cerneți, SW Romania.

\section{INTRODUCTION}

The studied area is located in Mehedinți District, next to Drobeta Turnu Severin town.

The W1 well from Cerneți (Fig.1) is $150 \mathrm{~m}$ deep and was performed by the SC FORADEX SA as a component of a large project named: "Water supply for Cerneț-Dedovița Nouă localities", during 2002. Because of the high content in $\mathrm{NaCl}$ of the water samples, the drill has been closed and there has been realized a number of lower depth drills for the same purpose of water supplying.

The intercepted sedimentary sequence (Fig.2) starts with the Upper Meotian deposits, consisting on sands and sandy clays with Congeria panticapaea, Psilunio subrecurvus etc.

In the studied perimeter, the Pontian deposits have a wide extension. In the W1 well, the sedimentary sequence assigned to the Early Pontian, starts at the base with gravels followed and ending with grayish clays.

\section{PALYNOLOGICAL STUDY}

The Meotian

From the lower sequence of the core, on an approximatively $40 \mathrm{~m}$ interval (from $\mathrm{m} 150$ to $\mathrm{m} 112$ ), consisting of clays and sandy clays, 9 samples subjected to further palynologic analysis, were collected. The microflora records are well preserved and the composition of pollinic spectra from different samples is mainly the same. Further on, we will consider for discussion only the samples 30 (m150) and 24 (m 126). 


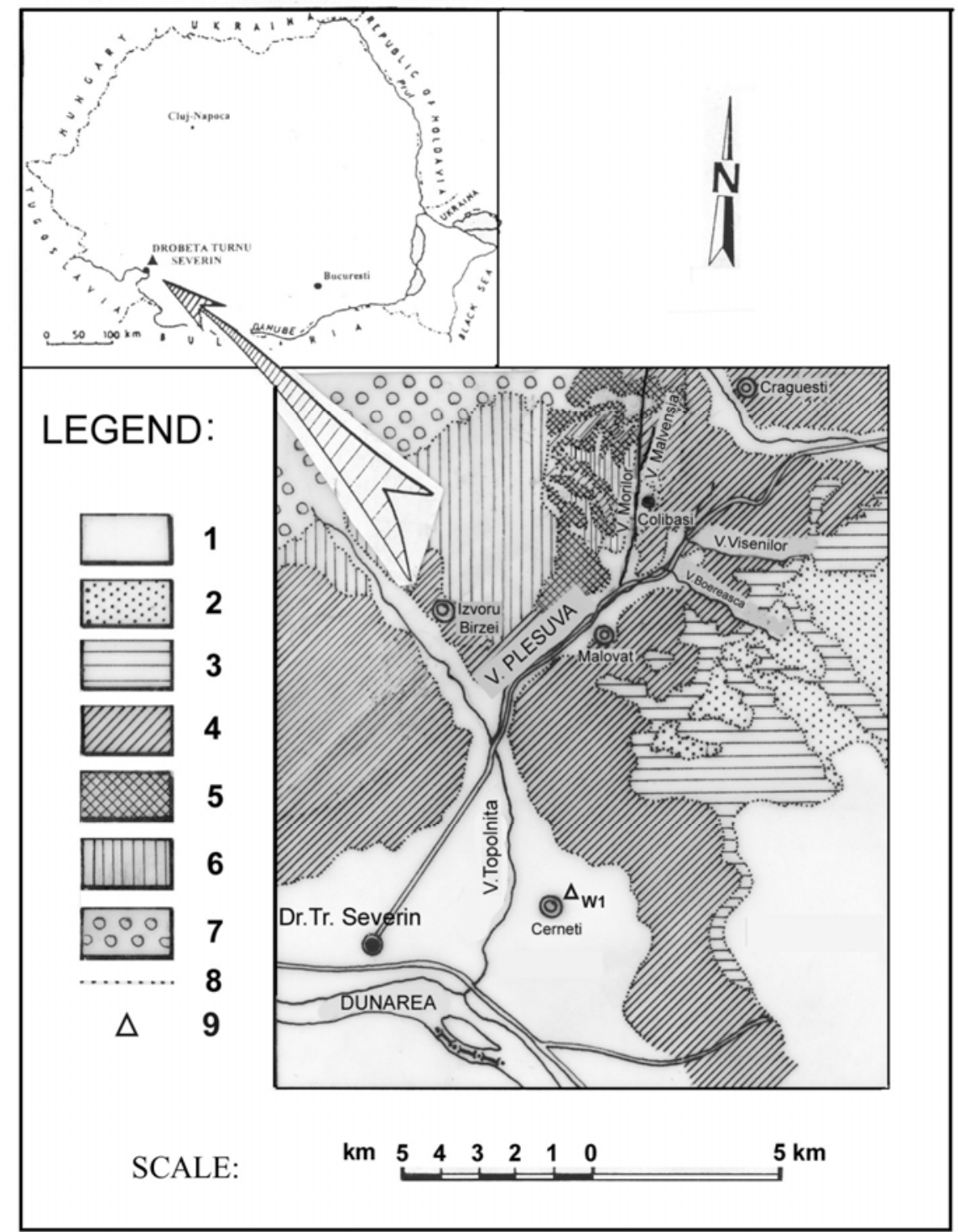

Fig.1. Location of the W1 Cerneți well (1 - Quaternary, 2-Romanian, 3-Dacian, 4 - Pontian, 5 - Meotian, 6 - Sarmatian, 7 - Badenian, 8 - geological boundary, 9 - drill (after the geological map of Romania, scale 1:200.000, modified).

The Sample no. 30 (m 150). FERNS - 3\%, CONIFERS - 62\%, (Taxodiaceae + Cupressaceae - 3\%, Pinaceae - 59\%), ANGIOSPERMS - 35\% (Monocotyledons $2 \%$, Dicotyledons - 33\%) (Fig. 2 ).

The Sample no. 24 (m 126). FERNS - 4\%, CONIFERS - 55\%, (Taxodiaceae + Cupressaceae $-2 \%$, Pinaceae $-53 \%$ ), ANGIOSPERMS $-41 \%$ (Monocotyledons $-1 \%$, Dicotyledons - 40\%) (Fig.2). 


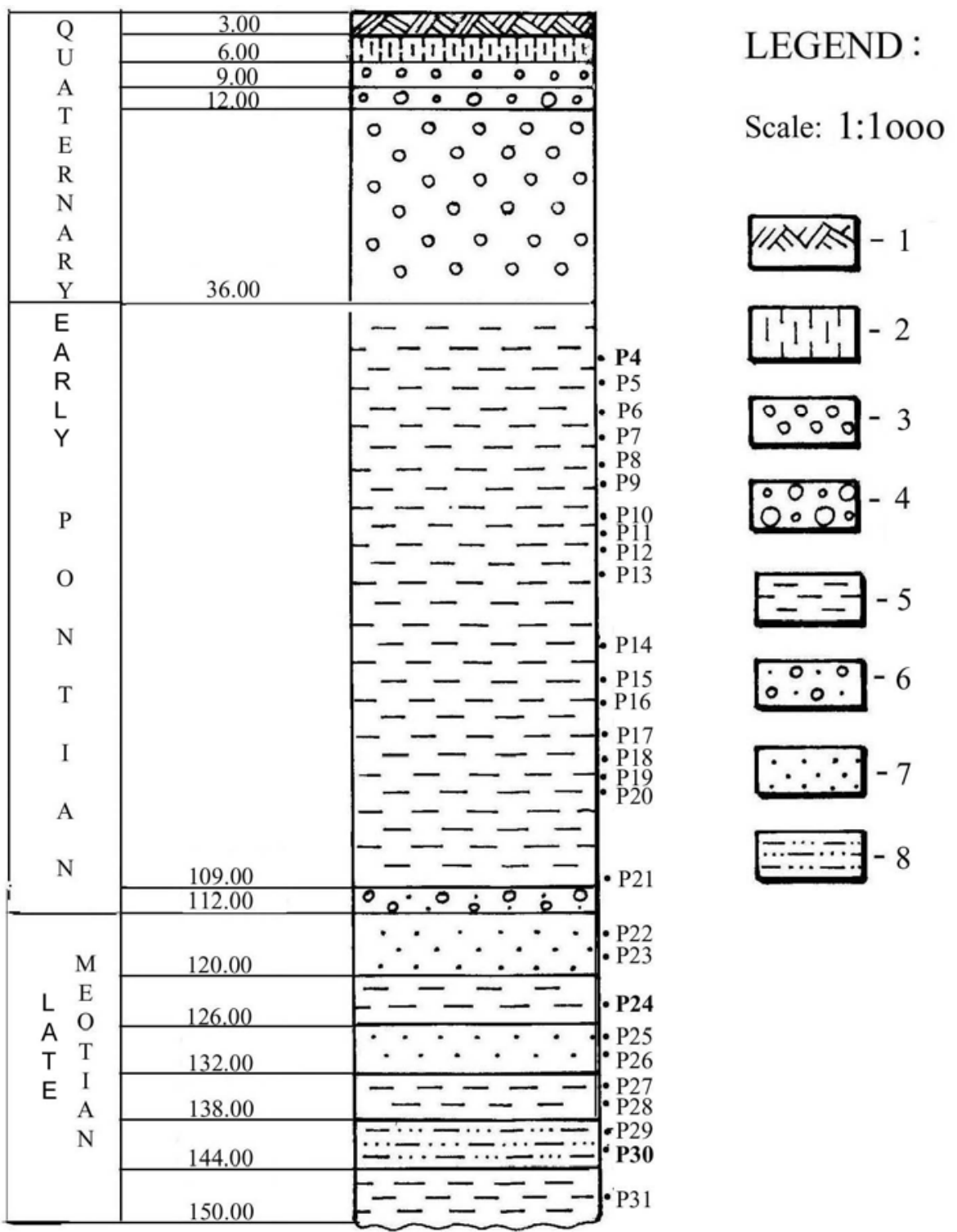

Fig. 2. Synthetic lithologic column of deposits crossed by the W1 well from Cerneți, indicating the samples locations (1 - vegetal soil, 2 - loess, 3-gravel, 4-gravel with rugged elements, 5-grayish plastic clay, 6-coarse sand with gravel elements, 7-grayish fine sand, 8-clayey fine sand)

On the whole, FERNS (3-4\%) are represented by Polypodiaceae (Laevigatisporites, Polypodiaceoisporites, Leiotriletes) and Osmundaceae (Baculatisporites) spores. 
CONIFERS (55-62\%) are evidence by Taxodiaceae + Cupressaceae (2-3\%) pollen and dominantly by Pinaceae $(53-59 \%)$ pollen.

From the first group we have identified: Sequoiapollenites polyformosus, Inaperturopollenites verrupapillatus, Cupressacites bockwitzensis and Sciadopityspollenites serratus.

The Pinaceae Familly is certified by: Pinus sg. diploxylon $-28-32 \%$, Pinus sg. haploxylon (+ Cathaya) $-15-16 \%$, Abies $-2-3 \%$, Picea $-4 \%$, Cedrus $-3-4 \%$, Tsuga-2\%, Keteleeria sub $1 \%$. sporadic.

The pollen of Ephedra - Ephedripites (Eph.) wolkenbergensis is absolutely

THE MONOCOTYLEDONOUS ANGIOSPERMS (1-2\%) are represented by monoporate pollen of Sparganium şi Graminiidites. Sporadically also might be identified de palm trees monocolpate pollen (Monocolpopollenites sp.).

THE DICOTYLEDONOUS ANGIOSPERMS (33-40\%) are frequent and represented by the pollen of Carya, Alnus, Ulmus. With a lower frequency it follows: Pterocarya, Quercus, Fagus, Betula and pollen of herbaceous plants (Tubulifloridites kozaniensis, Persicarioipollis welzowense, Chenopodipollis multiplex, Artemisiapollenites sellularis ş.a.). Rarely, pollen of Myrica, Carpinus, Momipites punctatus, Zelkova, Araliaceae, Juglans, Engelhardtia, Tilia, Ericaceae etc may be present.

Considering the ratio of participation between the main botanical groups, within it can be noticed the dominance of Pinacea pollen, the lower participation of Ferns and especially the Angiosperms composition (among of the pollen of herbaceous plants participate up to $3-4 \%$ ), it can be concluded that the pollen analyzed here show strong resemblance with the Meotian flora from the "upper horizon" (Late Meotian), identified in the Meotian deposits developed between Teleajen and Dâmbovița by Cioflică (1969, p.9). In the Late Meotian, studied by Cioflică, FERNS participates up to $2-6 \%$. The Pinaceae pollen is dominant: Pinus - $54-74 \%$, Picea $1-5 \%$, Abies $-1 \%$, Tsuga $-1 \%$. The Taxodiaceae pollen has a participation of $2 \%$. The herbaceous pollen participates with $2-4 \%$.

In the Late Neogene of Slovakia, Planderova (1990, p.101), separated the MF-9 palinozone, dominated by the Pinaceae (Pinus, Tsuga, Picea), temperate dycotiledonous (Ulmus, Betula), as well as by the xerofile herbaceous plants (Chenopodiaceae, Gramineae, Artemisia, Compositae). This palynozone is assigned to the Late Sarmatian and in lot of aspects show resemblances with our pollinic spectrum.

\section{The Pontian}

After a sequence dominated mainly by gravels and subordinately by loess and vegetal soil (of $36 \mathrm{~m}$ in thickness) is developed a sequence consisting of gravels at the lower part $(3 \mathrm{~m})$ and grayish clays at the upper part (73 $\mathrm{m}$ in thickness), assigned to the Early Pontian ( $112-\mathrm{m} 36$ ). There were palynologically analyzed a number of 18 samples keeping a quite uniform and well preserved microflora.

For the sample no. 6 ( $m$ 48) we have noticed the following participation percentages among the main botanical groups: FERNS - 5\%, CONIFERS - $60 \%$ and ANGIOSPERMS - 35\% (Fig.2).

FERNS $(5 \%)$ are sensitively numerous than those from the Meotian deposits. We noticed in this case also, a dominance of Polypodiaceae spores (Laevigatisporites haardti, L. gracilis, L. nutidus, Leiotriletes wolffi, Polypodiaceoisporites div.sp.). It can be found Echinosporis cf. echinatus, Favoisporis cf. trifavus, Stereisporites (St.) involutus etc. 
CONIFERS (60\%). The Taxodiaceae + Cupressaceae pollen is present under $1 \%$. It is represented by Inaperturopollenites hiatus, Sciadopityspollenites. On the other hand the Pinaceae pollen is dominant overall the pollinic spectrum (59\%). In this sample we have noticed the following participation percentages: Pinus sg. diploxylon $27 \%$, Pinus sg. haploxylon (+ Cathaya) $-10 \%$, Abies $-3 \%$, Cedrus $-4 \%$, Picea $-8 \%$, Tsuga - 6\%, Keteleeria under $1 \%$.

Scarcely might be found pollen of Ephedra.

THE MONOCOTYLEDONOUS ANGIOSPERMS (approximately 1\%) have the same consistency as in the lower sequence (the Meotian one).

\section{Sample 6}

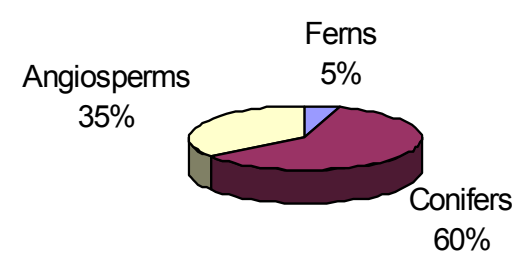

Sample 24

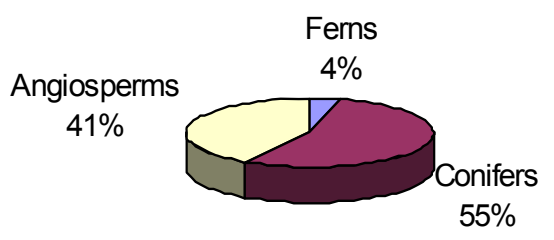

Sample 30

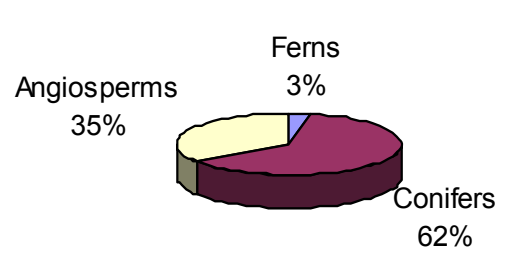

Fig. 3. The percentage diagram of the most important botanical groups (samples 6 - Early Pontian; 24 and 30 - Late Meotian)

THE DICOTYLEDONOUS ANGIOSPERMS (34\%) are on the second place (after conifers) in the pollinic spectrum of the Pontian. The pollen of Carya, Carpinus, Quercus, Ulmus, Fagus, Pterocarya is very frequent. The pollen of Betula, Myrica, 
Alnus, Eucomia, Engelhardtia, Juglans, Zelkova, Liquidambar, Tilia, Ericaceae is rare. The pollen of Manikinipollis tetradoides (considered to be Periploca pollen) appears to be singular, and is mentioned by Nagy $(1985$, p. 179) from the Sarmatian deposits in Hungary; here it might be a new presence in time of such tetrads. Actually in the Early Pontian from the Baraolt Basin (Petrescu et al., 1988, pl. II, fig. 12) this tetrad has been previously mentioned. Finally, in the Romanian from Gorj, this tetrad appears for the last time in Romania (Petrescu et al., 1987). Also the pollen of Scabiosaepollenites minimospinuosus described by Nagy $(1985$, p. 179) in Pannonian, is rare.

An important participation (approximately $5 \%$ ) has the pollen of xerofite plants: Tubulifloridites macroechinatus, T. grandis, Cichoreacidites gracilis, Chenopodipollis multiplex, Artemisiapollenites sellularis, Umbeliferae etc. The important participation of herbaceous plants specific for dry climate, indicates a continentalisation stage in the studied Pontian from Muntenia (Roman \& Papaianopol, 1982), respectively in Early and Late Pontian cross sections from Mehedinți (Petrescu et al., 2002), respectively (Petrescu et al., 2001).

\section{REFERENCES}

Cioflică, G., 1969, Studiul palinologic al depozitelor pliocene dintre Teleajen şi Dîmbovița (Rezumat Teză de Doctorat), 15p., Facultatea de Biologie, Universitatea din Bucureşti, Bucureşti;

Petrescu, I., Codrea, V., Pătruțoiu, I., Meilescu, C., 1987, Contributions à la connaissance de la géologie, de la paléontologie, de la palynologie et de la gènène des formations de charbon du pliocène supérieur (Romanien) de la zone Roşia - Peşteana - Turceni (Département dé Gorj), Studia Univ. B-B, s. Geologia-Geogr. XXXII, 2, 11-29, ClujNapoca;

Petrescu, I., Buda, A., Boer, H., 1988, Contributions to the Knowledge of Lignite Formation Palaeoenvironment in the Baraolt Basin (Eastern Carpathians), Studia Univ. BabeşBolyai, s. Geologie-Geogr. XXXIII, 2, 3-15, Cluj-Napoca;

Petrescu, I., Bican-Brişan, N., Meilescu, C., Pătruțoiu, I., 2001, Palynological researches concerning the Pontian on the Vişenilor Valley and Boereasca Valley - NE of Drobeta Turnu Severin (SW ${ }^{n}$ Romania), Studia Univ. Babeş-Bolyai, Geol., XLVI, 2, p. 95 - 109, 2 fig., 3 tab., 3 pl., Cluj-Napoca;

Petrescu, I., Bican-Brişan, N., Meilescu, C., Pătruțoiu, I., 2002, The palynology of the Pontian from Batoți - Mehedinți (south-western Romania). Acta Palaeontologica Romaniae, III, Third Romanian Symposium on Palaeontology, p. 347 - 358, 2 figs., 1 tab., 4 pls., laşi;

Planderova, E., 1990, Miocene microflora of Slovak Central Paratethys and its biostratigraphical significance, 144p.+ 86pl., D. Stur Inst. of Geology, Bratislava;

Roman, Şt., Papaianopol, I., 1982,: Données microfloristiques et macrofloristiques sur les depôts postmèotiens de la zone des plis diapires externes de Muntenie. Paleobotany Palynology Symposium, p. 80-87, Cluj-Napoca; 
PALYNOLOGY OF THE LATE NEOGENE, INTERCEPTED IN A BOREHOLE FROM CERNEȚI

\section{Plate 1 (Meoțian) (1000x)}

Fig. 1. Abies (Abiespollenites sivaki);

Fig. 2. Inaperturopollenites verrupapillatus;

Fig. 3. Pinus sg. haploxylon (Pityosporites alatus);

Fig. 4. Pinus sg. diploxylon;

Fig. 5. Tilia (Intratriporopollenites cordataeformis);

Fig. 6. Picea (Piceapollis tobolicus);

Fig. 7. Sequoiapollenites polyformosus;

Fig. 8. Chenopodiaceae (Chenopodipollis multiplex).

\section{Plate 2 (Ponțian) (1000x)}

Fig. 1. Abies (Abiespollenites absolutus);

Fig. 2. Periploca (Manikinipollis tetradoides);

Fig. 3. Sphagnaceae (Stereisporites (St.) stereoides);

Fig. 4. Picea (Piceapollis planoides);

Fig. 5. Cedrus (Cedripites crassiundulicristatus);

Fig. 6. Leiotriletes wolffi; 


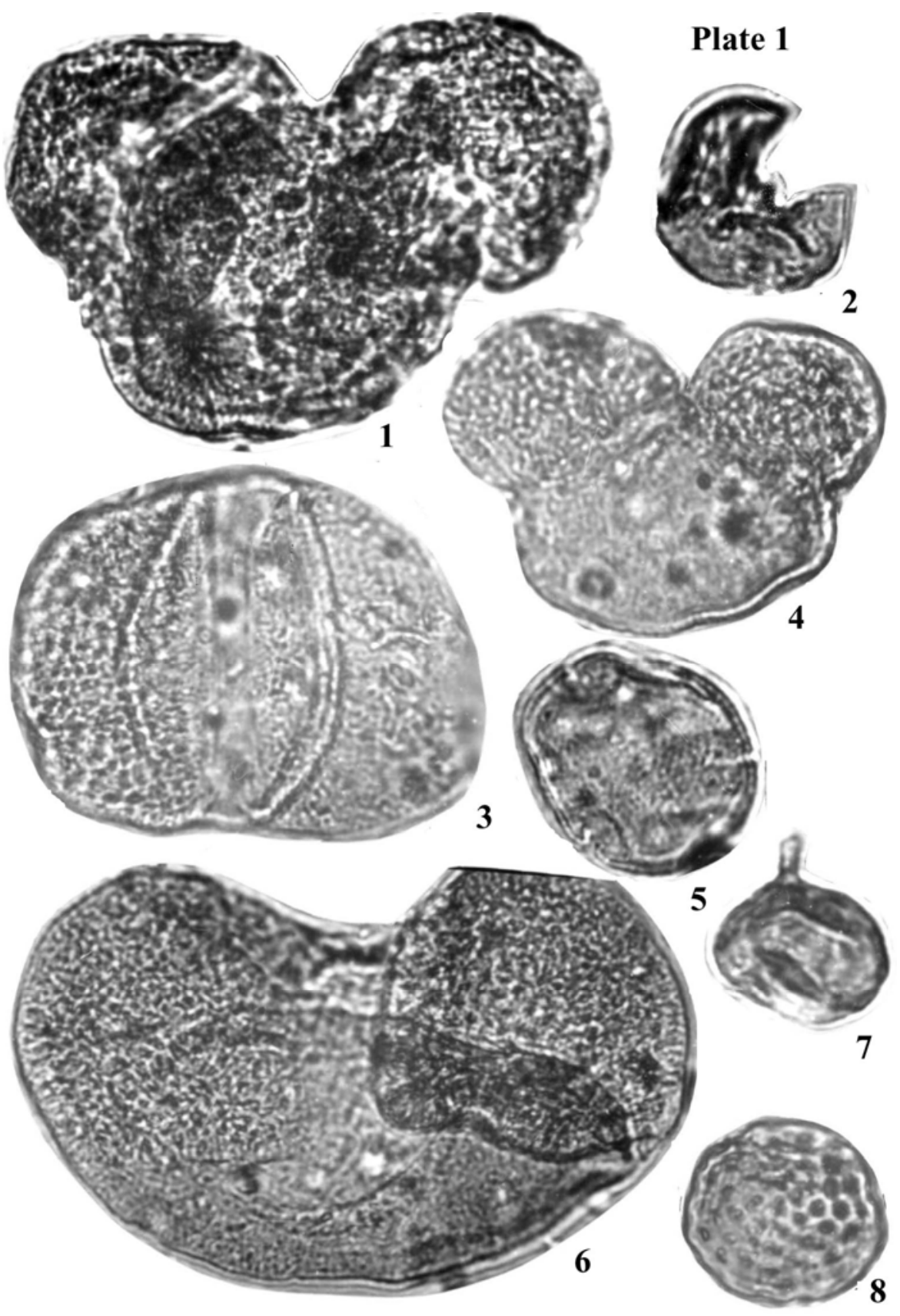




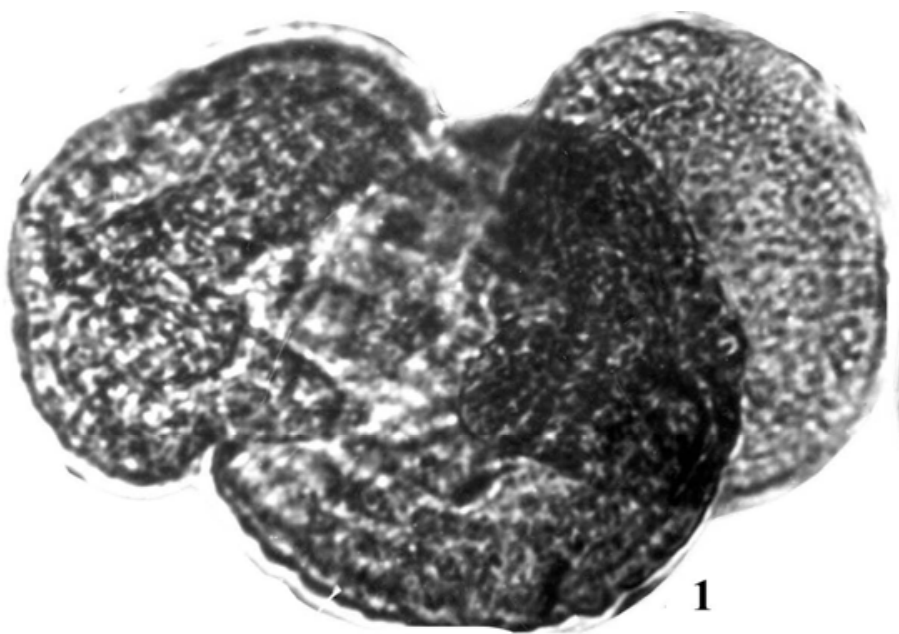

\section{Plate 2}
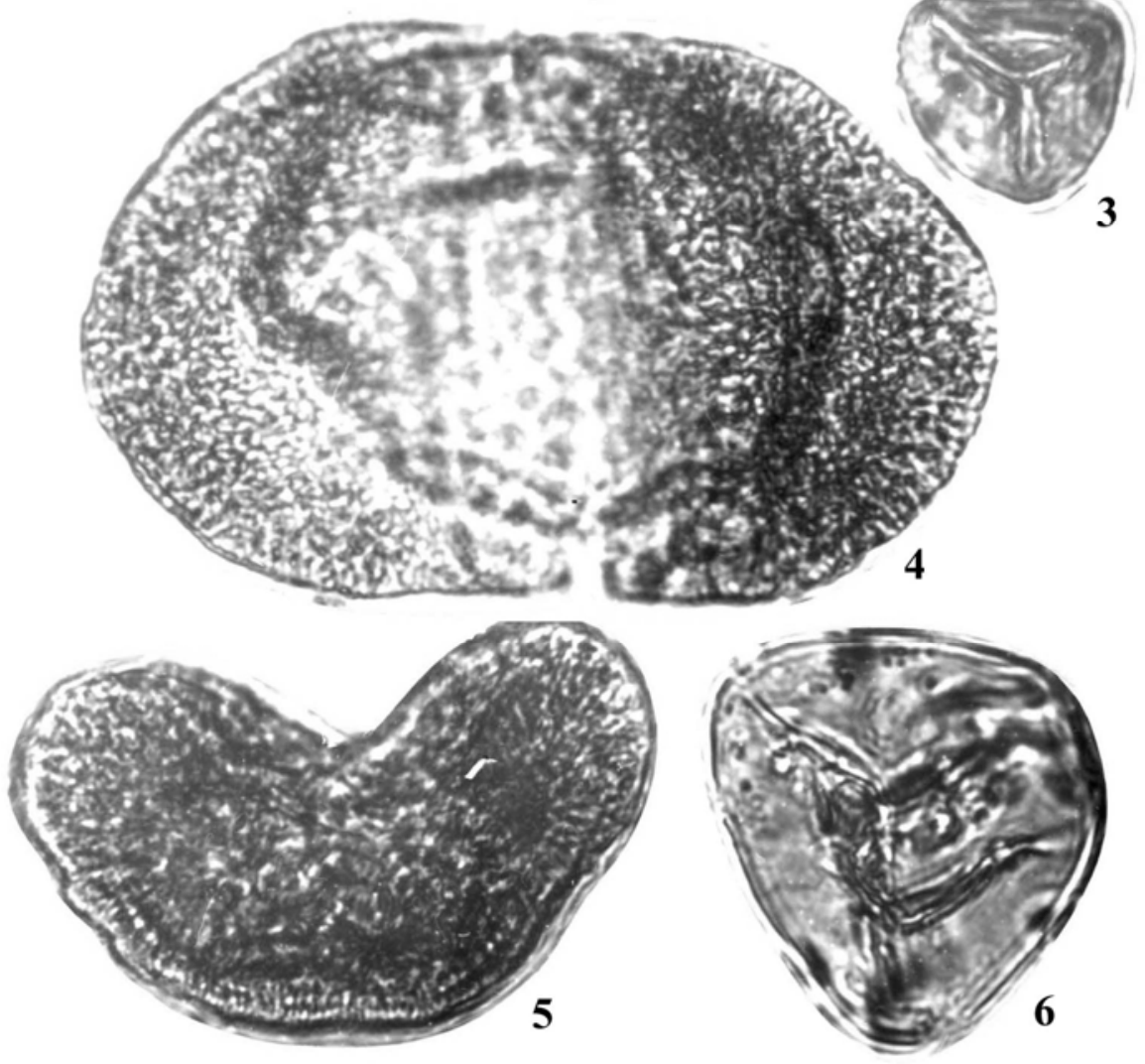